\title{
Storage of grains and technical plants through active ventilation for the purpose of maintaining the quality of stored products
}

\author{
Anişoara Păun ${ }^{1,}$, Gheorghe Stroescu ${ }^{1}$, Alexandru Zaica ${ }^{1}$, Samir Yasbeck Khozamy ${ }^{2}$, Ana \\ Zaica $^{1}$, Oana Cristea $^{1}$, Vasilica Ştefan ${ }^{1}$, and Carmen Bălţatu ${ }^{1}$, \\ ${ }^{1}$ National Institute of Research - Development for Machines and Installations designed to \\ Agriculture and Food Industry - INMA, Bucharest 013813, Romania \\ ${ }^{2}$ Schneider Electric / Romania
}

\begin{abstract}
The problem of grain storage and storage can be approached from two perspectives: storage and storage of cereals and technical plants within individual agricultural holdings; storage and storage of cereals and technical plants within agricultural associations and companies. At the level of Romania, the storage and storage of cereals at small agricultural producers are deficient in terms of ensuring optimal storage conditions according to standards. These variants include: preservation at low temperatures; preservation by active aeration; self-preservation; chemical preservation; conservation with the help of radiation. In the paper we will approach the conservation by active aeration because it folds better for small agricultural producers. Proper aeration is one of the most important processes in a grain storage system and is essential for maintaining the quality of stored products. Aeration means the movement of a relatively small volume of air through the grain mass in order to control the temperature of the grain and to reduce the risk of product degradation. The two main objectives of aeration are to maintain a uniform temperature in the grain mass and at the same time the temperature must be as low as possible from a practical point of view. The paper will present the results of experiments for storing bulk grain in a metal cell with central aeration system, which is based on a patent. This type of storage system can be used successfully in small agricultural producers.
\end{abstract}

\section{Introduction}

Prior to processing, agricultural products must be stored in optimal storage conditions to ensure maximum preservation of long-term nutritional qualities and to eliminate depreciation of biological properties. Cereals are the most important staple food for humans. Of the amount of grain harvested worldwide, more than $20 \%$ is lost annually, mostly due to insect activity and the development of fungi and molds, due to inadequate storage. The technical storage conditions are closely correlated with the technologies for

\footnotetext{
* Corresponding author: ani_paun@yahoo.com
} 
storage and conservation of bulk cereal seeds, with the crop species, with their subsequent destination and with the geographical area in which they are located (meteorological and vegetation conditions specific to the products reaching humidity and the optimum storage temperature) [1,2]. Keeping the seeds after harvest even just a few days with a high moisture content (over 18\%) reduces the germination below the standardized limit $(90 \%)$, thus eliminating the possibility of using these seeds in the process of establishing new crops. The seeds must be cleaned before being stored $[3,4]$. For seeds intended for storage, the conditions for preserving the nutritional and organoleptic qualities (taste, smell, aroma, etc.) must be ensured. The presence of weed seeds can lead to degradation of the main crop seeds during storage, as they have a higher humidity and create foci of heat, causing mold and spoilage, they are also favorable environments for the development of microorganisms and pests [5]. Cracks, undeveloped or damaged seeds are less resistant to storage, being easily attacked by molds and pests, etc. All these considerations impose the necessity and the obligation of the pre-cleaning and cleaning of the seeds in order to ensure optimal conditions for storage, storage, marketing, consumption, sowing material, etc. Regarding the storage and conservation systems of agricultural products in the form of seeds, the most rational and economical system for Romania is that of dry storage (for a long time). According to this system, cereal and legume seeds are harvested when they have reached biological maturity and have a humidity below $14 \%$ in the case of straw cereals and seed corn, less than $11 \%$ in soybeans and less than $8 \%$ in sunflower In recent years, there have been more efficient ways of preserving cereals with greater or lesser applicability in agricultural practice. These variants include: preservation at low temperatures; preservation by active aeration; self-preservation; chemical preservation; radiation preservation. Aeration preservation is a method that can be applied both to large agricultural farmers but also to small agricultural producers, both for cereal seeds and technical plants and for feed (hay) [6-10]. Proper aeration is one of the most important processes in a grain storage system and is essential for maintaining the quality of stored products. A properly used aeration system helps control insect infestations and moisture migration, reducing grain damage and saving money. Normally, cereals stored for more than a few weeks should be aerated. Aeration means the movement of a relatively small volume of air through the mass of grain in order to control the temperature of the grain and reduce the risk of product degradation.

In commercial practice, the method of transferring cereals (moving them from one silo cell to another) for temperature control and eliminating hot spots has largely been eliminated. Within INMA, a series of technologies, technical equipment for cleaning and storage have been developed and tested [11-13]. The paper presents some of the results obtained and the conclusions regarding the optimal aeration system based on a patent [14].

\section{Materials and methods}

The humidity in the seed, the high air temperature, the thickness too large of the stored seed layer, can determine a fast and intense evolution of the infections, leading to the decrease of germination and to the depreciation of the biological and agronomic value of the seeds. Damage that occurs to seeds stored for a long time is reflected by [5]:

- loss of germination capacity;

- $\quad$ increasing the number of abnormal germs;

- increasing sensitivity to unfavorable environmental conditions;

- decrease in metabolic activity.

Cereals should be aerated as soon as possible after being stored. This is particularly important if there are large variations in temperature or humidity or if the whole cereal mass is initially hot. In autumn, the temperature of the grain must be reduced to approach 
the average outside temperature. INMA developed and tested storage equipment for cereal seeds and industrial plants, figure 1. Installation for storage and preservation of cereals is a complex, modern plant for straw cereals (wheat, barley, rye), corn, legumes and oilseeds, species with a large share in all agricultural production on small and medium farms, which ensures the cleaning of cereals and their aeration during storage.

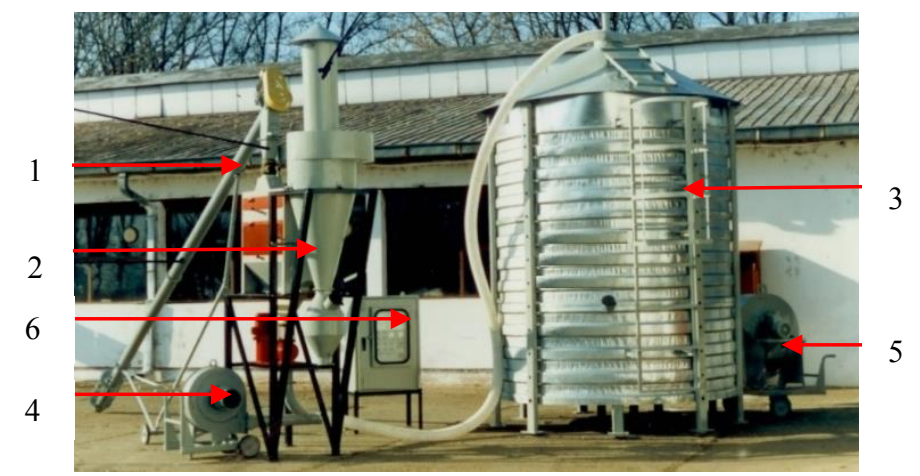

Fig. 1. Installation for storage and preservation of cereals ISC10

The ISC 10 storage and preservation installation has the following components: 1screw conveyor; 2-group cleaning; 3- storage cell; 4- mobile pneumatic transport installation; 5- mobile aeration installation; 6-power and control electrical installation. The constructive solution for the storage cell of figure 1, was the basis for the realization of the patent no. 126266 / 30.05.2016, figure 2,

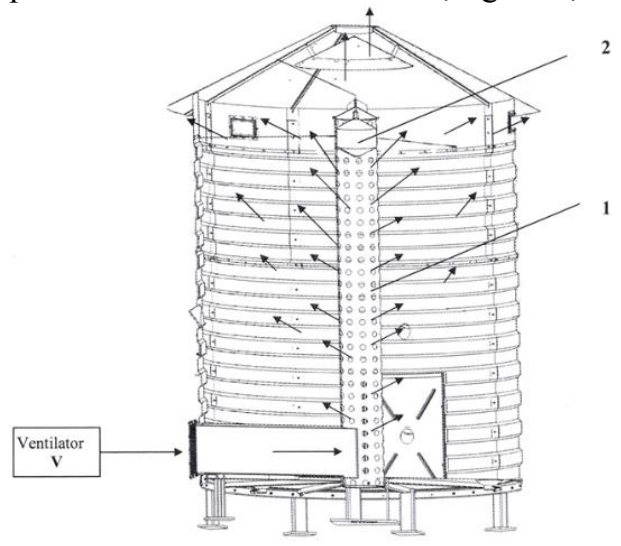

a

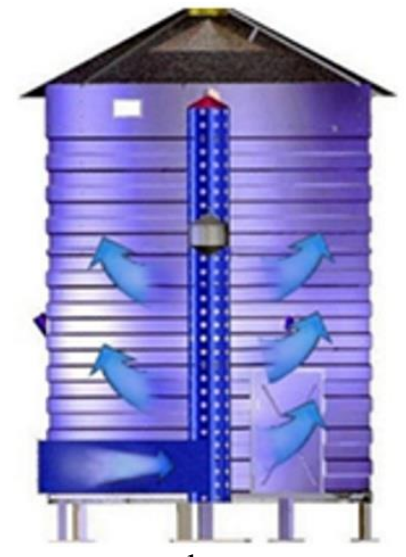

b
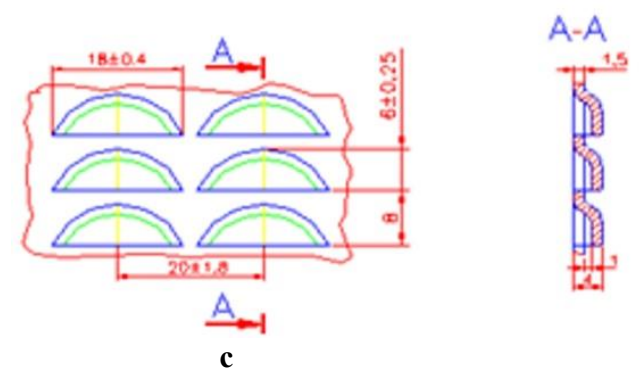

Fig. 2. Storage cell according to the patent [14]

a: 1- central aeration column; 2- adjusting device; b-storage cell 3D; c-storage cell wall detail 
The storage cell is a metal construction, cylindrical in shape, removable, with corrugated galvanized sheet walls that alternate with special walls, also made of galvanized sheet, which allow natural and artificial aeration. At the top inside the storage cell is mounted a cone that achieves a uniform distribution of the product in the cell, around the central aeration column. According to the patent, figure 2, the central aeration column is a metallic, cylindrical construction, made of perforated sheet. Aeration is done both naturally, through the storage cell walls (cell wall detail) and controlled, through the central aeration column, made of perforated sheet. The air flow required for this process is ensured by the mobile aeration installation connected through the special piping, at the base of the central aeration column of the storage cell. Given the need for the correct development of the process and its special importance, the air flow required for aeration was calculated. Insufficient amount of blown air causes water vapor to condense in the upper layers of the seed mass. Proper aeration occurs when the air leaving the seed mass has a relative humidity below $80 \%$. The cooling and drying process during active aeration proceeds as follows: during the insufflation of cold and dry air, it first meets the lower layer, where it forms a transitional front, in which there is a decrease in seed temperature and humidity, while in the upper area the temperature and humidity of the seeds increase slightly. As the operation continues, this front or transition zone moves in the direction of the blown air stream until it reaches the surface of the bulk. The area where the changes in temperature and humidity between the blown air and the seeds take place, limited by both the properties of the air current and those of the grain mass, ensures a relatively large exchange area, depending on the species.

For a more efficient distribution of the blown air in the areas that require it, the aeration column is provided inside, with an adjusting device that can move vertically by closing / releasing various areas of the side surface of the column. The purpose of aeration consists in: controlling the temperature of cereals; low temperature storage; moisture migration, figure 3; elimination of foreign odors; modification or equalization of humidity in the product mass; fumigation; keeping cereals with higher humidity.

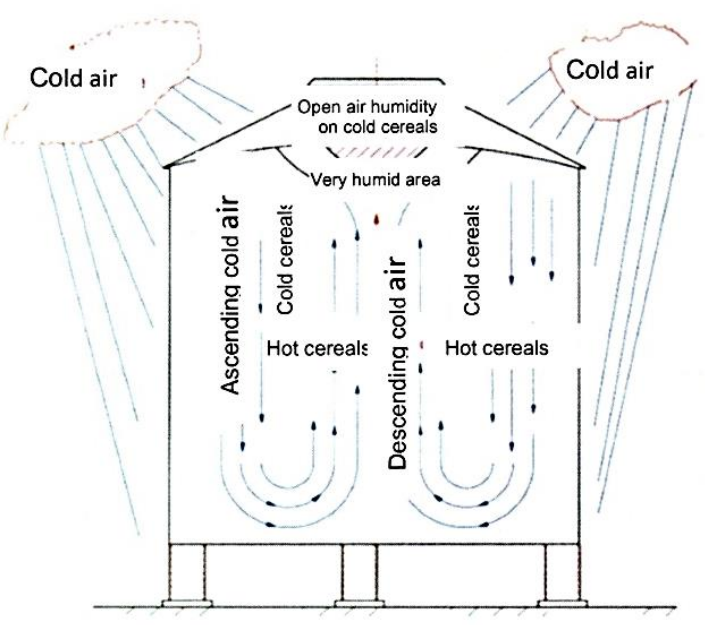

Fig. 3. Moisture migration in autumn and winter

Temperature deviations between seed mass and ambient outside air cause moisture migration problems. Figure 3 illustrates a typical migration phenomenon in cold weather (autumn and winter), caused by lower ambient temperatures. Because the dry product mass 
has a thermal insulating effect, the product on the sides of the cell changes its temperature faster than the product mass located in the center of the storage cell.

Temperature differences in the mass of the product cause air currents from the hot mass to the cold mass of the product. The direction of these currents depends on how the product cools if the temperature outside the cell drops or heats up if the temperature outside rises during spring and summer. In autumn and winter, the product mass, figure 3 , next to the cell walls and under the roof is colder, the product mass in the middle of the cell having a higher temperature. Moisture-laden air rises, passes through the colder product layer where it leaves moisture. The airflow then moves down the cell wall to replace the volume of warm air in the center of the cell, thus closing the convection cycle.

The balance of moisture content for a given species depends on the relative humidity of the air and the storage temperature. Relative humidity is given by the relation:

$$
\varphi=\frac{g_{\mathrm{v}}}{g_{\mathrm{s}}} \times 100 \%
$$

where:

$\mathrm{g}_{\mathrm{v}}$ - weight of water vapor in $\mathrm{a}^{3}$ of humid air, $\mathrm{kg} / \mathrm{m}^{3}$;

$\mathrm{g}_{\mathrm{s}}$ - the maximum weight of vapors at the same volume, $\mathrm{kg} / \mathrm{m}^{3}$.

Amount of air to be blown (Q) is expressed in $\mathrm{m}^{3}$ air / hour / ton of seed (sometimes in $\mathrm{m}^{3}$ air / hour $/ \mathrm{m}^{3}$ of seed) and is calculated using the relation:

$$
\mathrm{Q}=\frac{D}{G}
$$

in which:

D- air flow supplied by the fan, $\mathrm{m}^{3} / \mathrm{h}$;

G- weight of the batch subjected to aeration, $t$.

The number of air exchanges must also be taken into account when calculating the amount of air required for active aeration in the storage cells. The required number of hourly air changes in the intergranular space varies depending on the seed moisture and is calculated using the relation:

$$
\mathrm{N}=\frac{D}{P}
$$

in which:

D- the air flow supplied by the fan, $\mathrm{m}^{3} / \mathrm{h}$;

P- the porosity of the seed mass.

For the seeds of the main species the porosity of the mass is the following: wheat 35 $45 \%$, barley $45-55 \%$, oats $50-79 \%$, corn $30-50 \%$, sunflower $60-80 \%$, linseed oil $30-50 \%$.

\section{Results and discussions}

The experiments were performed with the installation shown in figure 1. After the precleaning process, experiments were performed following the equilibrium humidity of the cereal seeds, at different temperatures. The experiments were performed on seed lots of: wheat, corn, barley and rice, ( tables 1, 2 and 3). For the correct evaluation of the results were determined in the laboratory the characteristics of the seeds subjected to the precleaning operation. The results of the experiments are presented in the graphs in figures 4,5 and 6. 
Table 1 Operating indices - the equilibrium humidity of cereal seeds at different temperatures

\begin{tabular}{|c|c|c|c|c|c|c|c|c|c|}
\hline \multirow{2}{*}{$\begin{array}{c}\text { Seed product } / \\
\text { temperature, }\end{array}$} & \multicolumn{10}{|c|}{$\mathrm{C}$} & 10 & 20 & 30 & 40 & 50 & 60 & 70 & 80 & 90 \\
\hline Wheat $/ 20^{\circ} \mathrm{C}$ & 0 & 3.9 & 7.2 & 10.7 & 11.8 & 13.1 & 14.8 & 16.5 & 20.1 \\
\hline Barley $/ 20^{\circ} \mathrm{C}$ & 0 & 8.3 & 9.5 & 10.9 & 12.0 & 13.4 & 15.2 & 17.5 & 20.9 \\
\hline Barley $/ 25^{\circ} \mathrm{C}$ & 0 & 6.4 & 8.8 & 10.7 & 11.8 & 13.3 & 15.9 & 19.1 & 24.9 \\
\hline Corn $/ 20^{\circ} \mathrm{C}$ & 0 & 8.2 & 9.4 & 10.7 & 11.9 & 13.2 & 14.9 & 16.9 & 19.2 \\
\hline
\end{tabular}

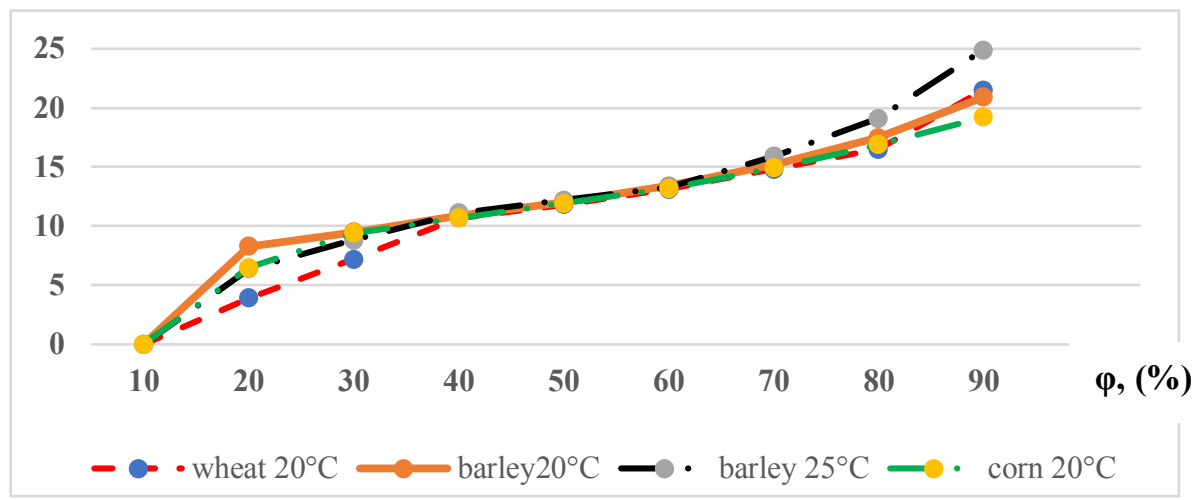

Fig.4 Balance curves for different grains

Analyzing figure 4 we find the balance of moisture content for a particular species depends on the relative humidity of the air and the storage temperature.

Table 2 Operating indices when drying by active aeration of cereals.

The difference between the temperature of the seed mass and the air outside the cell. (0C)

\begin{tabular}{|c|c|c|c|c|c|c|c|c|c|}
\hline \multirow{2}{*}{$\begin{array}{c}\text { Grain } \\
\text { moisture, } \\
\%\end{array}$} & \multicolumn{8}{|c|}{ Air Relative Humidity $\boldsymbol{\varphi , ~ ( \% ) ~}$} \\
\cline { 2 - 11 } & 60 & 65 & 70 & 75 & 80 & 85 & 90 & 95 & 100 \\
\hline 17 & - & - & - & 0 & 0.4 & 1 & 2 & 2.9 & 3.4 \\
\hline 16 & - & - & - & 0 & 1 & 1.9 & 2.7 & 3.6 & 4.3 \\
\hline 15 & - & - & 0 & 1 & 1.9 & 2.9 & 3.9 & 4.9 & 5.5 \\
\hline 14 & - & 0 & 1.3 & 2.2 & 3.1 & 4.1 & 5 & 6 & 7 \\
\hline
\end{tabular}

Mobile aeration installation position 5, within the ISC10 grain storage and preservation installation, figure 1 can ensure through the provided fan an air flow of $4500 \mathrm{~m}^{3} / \mathrm{h}$. 


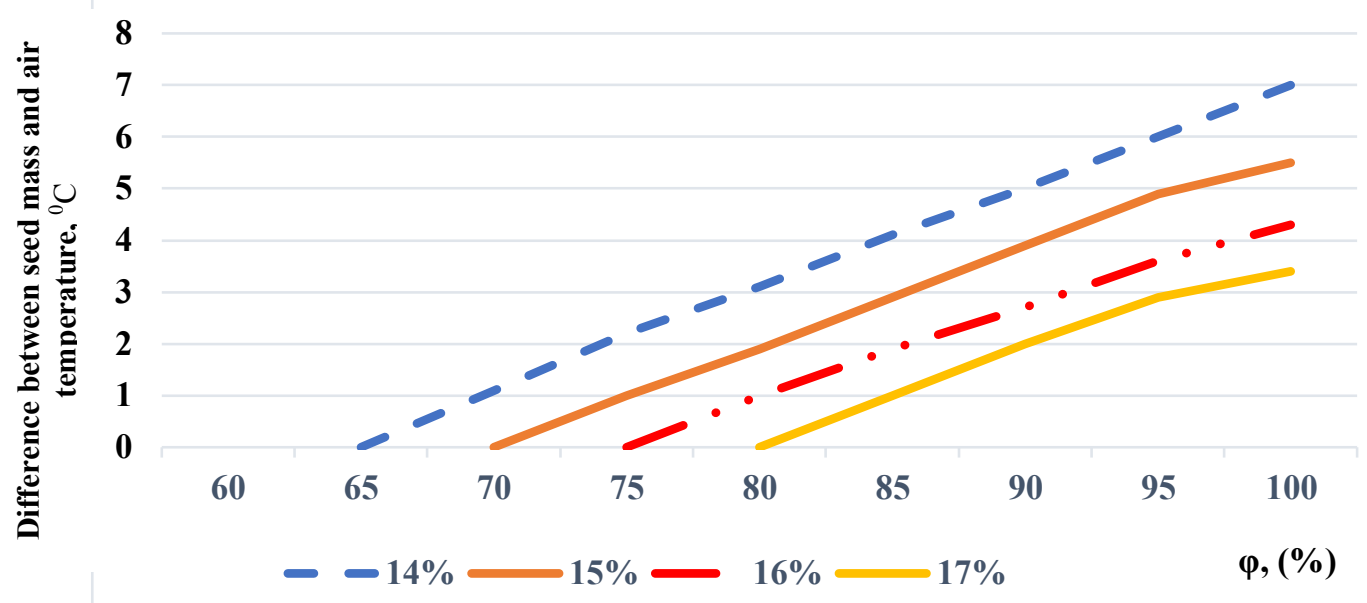

Fig. 5 Drying cereals by active aeration

Analyzing the graph in figure 5, it is found that if there is no temperature difference between the seed mass and the air, the drying can take place only at a relative humidity $\varphi$, of the air below $65 \%$. If a relative humidity $\varphi$ of the air is $95 \%$ the temperature difference must be $60{ }^{0} \mathrm{C}$, to bring the seeds to a humidity of $14 \%$ or $2.90{ }^{0} \mathrm{C}$ to be brought to a humidity of $17 \%$.

Table 3 Operating indices when cooling cereals by active aeration

\begin{tabular}{|c|c|c|c|c|}
\hline \multirow{2}{*}{$\begin{array}{l}\Delta \mathbf{T} \\
\mathbf{0}^{\mathbf{C}}\end{array}$} & \multicolumn{4}{|c|}{ Required air flow, $\mathbf{~} \mathbf{3} / \mathbf{h} / \mathbf{t}$} \\
\cline { 2 - 5 } & $\mathbf{5 0}$ & $\mathbf{1 0 0}$ & $\mathbf{1 5 0}$ & $\mathbf{2 0 0}$ \\
\hline 1 & 0.03 & 0.04 & 0.06 & 0.09 \\
\hline 2 & 0.06 & 0.07 & 0.11 & 0.15 \\
\hline 3 & 0.08 & 0.1 & 0.15 & 0.23 \\
\hline 4 & 0.09 & 0.15 & 0.23 & 0.29 \\
\hline 5 & 0.12 & 0.2 & 0.3 & 0.35 \\
\hline 6 & 0.13 & 0.25 & 0.35 & 0.45 \\
\hline 7 & 0.15 & 0.29 & 0.42 & 0.52 \\
\hline 8 & 0.18 & 0.33 & 0.51 & 0.58 \\
\hline 9 & 0.18 & 0.37 & 0.6 & 0.72 \\
\hline 10 & 0.2 & 0.4 & 0.68 & 0.8 \\
\hline
\end{tabular}

Note: It was noted with $\Delta \mathbf{T}$ temperature reduction, in an aeration hour ${ }^{0} \mathrm{C}$. 


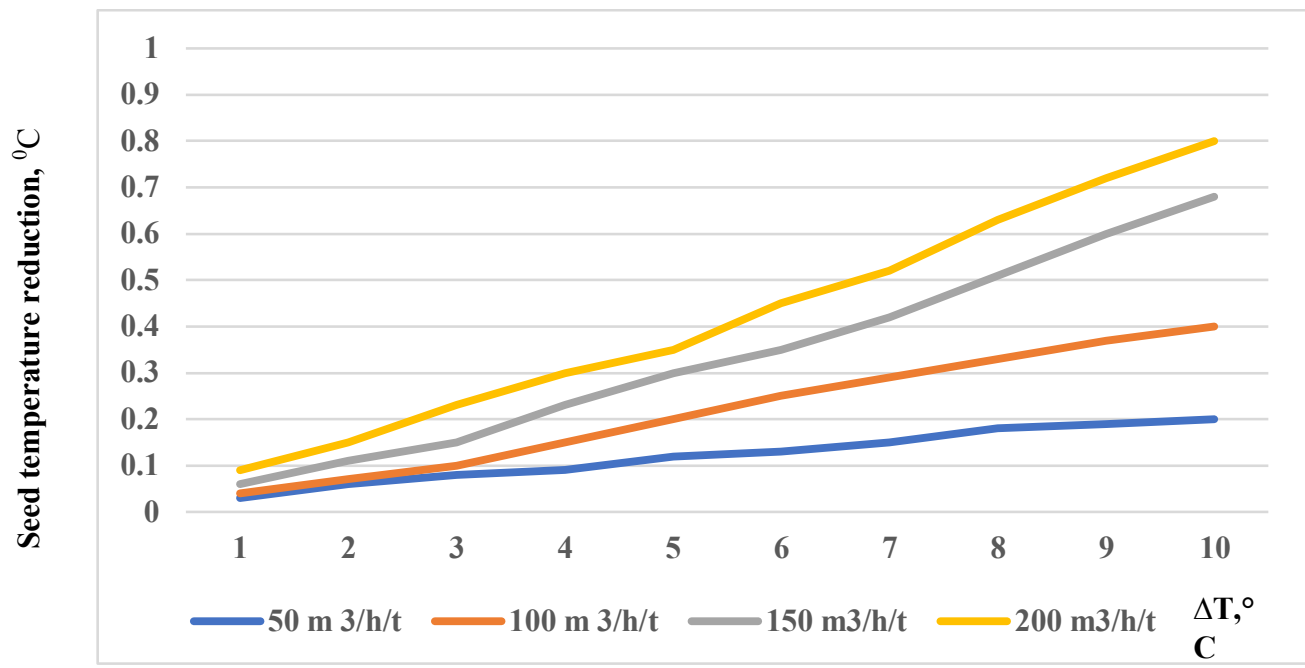

Fig. 6 Cooling of cereals by active aeration

Aeration should take place as soon as the average outside air temperature is at least $5^{\circ} \mathrm{C}$ colder than the hottest temperature in the silo. Cooling takes place in stages until whole grains reach 0 to $-5^{\circ} \mathrm{C}$. In the spring, the heating of the cereals should be done if it is planned to be kept for an extended period of time (after June) or if the temperature of the cereal mass is below $0^{\circ} \mathrm{C}$. If necessary, the fans are activated as soon as the average outside temperature reaches $5-7^{\circ} \mathrm{C}$ above grain temperature.

\section{Conclusions}

- For short-term storage, cereal seeds must be pre-cleaned (when many foreign bodies have resulted from the threshing operation), not infested and have a maximum moisture content of $16 \%$ in the case of straw cereals or maize, $13 \%$ in soybeans and a maximum of $11 \%$ for sunflower;

- For long-term storage, the seeds must be cleaned and have the qualitative parameters of the finished product standard, in correlation with the stored species and its destination (for sowing, consumption or industrialization);

- Cereals with more than $17 \%$ humidity can be stored, until drying, for short periods of time, in spaces provided with active aeration installations;

- It should be noted that the humidity increases with decreasing temperature and decreases with increasing temperature;

- Cereals, legumes and oilseeds with humidity above the limits provided in the delivery standards, will be dried in a shorter period of time the higher the humidity;

- The storage life of stored cereal seeds depends on a series of technical, economic and strategic factors, all of which are correlated with atmospheric conditions, the quality of thermal insulation, etc.

This paper was financed with:

- the support of National Agency for Scientific Research and Innovation, Programme FARMING TOMORROW - ENSURING ENVIRONMENT SUSTAINABILITY BY INCREASING COMPETITIVENESS OF IMPROVEMENT FOR ECOLOGICAL AGRICULTURE (UEFISCDI PN-III-P1-1.2-PCCDI-2017- 0850, Contract: 14PCCDI/06.03.2018), project component 4 "Making efficient the technology of producing ecological seeds for legume species by achieving a module of seed conditioning". 


\section{References}

1. N. Bucurescu, D.Roman, Seed and its preparation for sowing, Ceres Publishing House, Bucharest (1992)

2. A. Paun, P.Gageanu, I. Chih Li-Hua, Al. Zaica, A.Canpeanu, Symposium - INMATEH Agricultural Engineering, 46-50, Vol. 29, No.3 (2009)

3. Gh. Stroescu, A. Paun, I.Voicea, C.Persu, A. Matache, G. Bunduchi, , Proceedings of 19th International Scientific Conference Engineering for Rural Development Jelgava, 1277 - 1283, DOI:10.22616/ERDev.2020.19.TF315 (2020)

4. Gh. Stroescu, A. Paun, C. Bracacescu, M. Olan, Proceedings of 18th International Scientific Conference Engineering for Rural Development Jelgava, 34-38 (2019)

5. D.D.Plăcintă Micromycetes that are transmitted through the seeds of straw cereals prevention and control, Editura Universităţii din Suceava, (2007)

6. A. Zaica, A. Nedelcu, R. Ciuperca, L. Popa, Al. Zaica, C. Sorica, ISB, 723-730, (2016)

7. A. Zaica, A. Nedelcu, R. Ciuperca, L. Popa, Al. Zaica, C. Sorica, 45th International Symposium "Actual Tasks on Agricultural Engineering”, Croatia, 546-556 (2017).

8. A. Zaica, A. Nedelcu , Al. Zaica, R. Ciuperca , L. Popa, C. Mircea, TE-RE-RD, 495500, (2017).

9. A. Zaica, A. Nedelcu , R. Ciuperca, Al. Zaica, $17^{\text {th }}$ International Scientific Conference "Engineering for Rural Development", Jelgava, LATVIA, 115-123 (2018).

10.A. Zaica, A. Nedelcu, R. Ciuperca, Al. Zaica, A.-L.Visan, TE-RE-RD, 2457-3302, (2019).

10. A. Zaica, R. Ciupercă Al. Zaica, Diana Popa, $19^{\text {th }}$ International Scientific Conference "ENGINEERING FOR RURAL DEVELOPMENT", Jelgava, LATVIA, 16411647,(2020)

11. Ciobanu V.G., A.L. Visan, Paun A, Nedelcu A. JoKULL Journal, Vol.64, No.9, 91-100 (2015).

12. A.Paun, Ghe. Stroescu, Al.Zaica, G. Bunduchi, A. Zaica, C-tin. Bogdanof, D-tru. Milea, S.Yasbeck Khozamy, O.D.Cristea, L.C.Cristea, ISB-INMA TEH',814-821, (2020)

13. Experimentation report, ISC10 grain storage and preservation plant (2014)

14. A. Paun, I. Pirna, I. Cojocaru, I. Ganea-Christu, Patent no. 126266/30.05.2016 